\title{
Om »ægte Tydsk» og om de tyske »Hjertesprog« i Grundtvigs forestillingsverden
}

\author{
Af Horst Nägele \\ Sammenfattende gengivelse på dansk
}

Hensigten med forfatterens korte fremstilling er at forklare noget om bevæggrundene til Grundtvigs kritik af den tyske idealisme, der indledningsvis sammenstilles med Jens Baggesens kritik af Fichte og Søren Kierkegaards kritik af Hegel.

Forfatteren går ud fra den hypotese, at denne kritik må forklares udfra disse kritikeres eget standpunkt, i spændingsfeltet mellem det tyske litteratursprog og modersmålet, som det fuldbyrder sig i talen her og nu. Det tyske litteratursprog repræsenterer ligesom det latinske en blot spekulativ enhed af indbyrdes forskellige elementer; modersmålet er et mere virkelighedsnært, snarere dialektalt udtryksmiddel. Forfatterens fremgangsmåde bestyrkes af de mange eksempler, man hos Grundtvig kan finde på modstillingen af Højtydsk (ikke sjældent i forbindelse med Latin) og Dansk. Dette gælder især de skrifter af den senere Grundtvig, der vidner om hans interesse for den regionale folkeligheds elementære rettigheder. Selvom disse mangfoldige belæg $\mathrm{i}$ deres ensidighed og politiske engagement ikke umiddelbart fører til erkendelse af almengyldige strukturelle lovmæssigheder, kan de dog give anledning til efterforskning af beslægtede tankegange i Grundtvigs øvrige værk, særlig fra i 81 o-ı 820. Arbejdet er i så henseende en fortsættelse af William Michelsens studie over skriftet Europa, Frankrig og Napoleon fra 18 I5 (Grundtvig-Studier I 955 S. 4 off).

Grundtvigs fremstilling af forskellige kulturnationers karakteregenskaber bygger i fremtrædende grad på sproget som kendetegn. Det franske sprog betegnes f. eks. som det flygtigste og tommeste i Europa, som skummet på vandet eller vinen fra Champagne. Denne dristige sammenligning begrundes senere med, at vi først begriber franskmændenes sprog, smag og liv i det hele taget, når vi har lært 
at betragte dem som skummet på den europæiske folkestrøm. Sådanne sammenligninger giver indtrykket af en slags ordakrobatik, hvis man ikke kender baggrunden i skriftet som helhed. Grundtvig går nemlig a priori ud fra et oprindeligt fællessprog for menneskeslægten, et Hjertesprog, som han siger, som medium for sandheden. Den først efterhånden indtrådte sprogforvirring forklarede han allerede i sin Verdens Krønike I814 med det bibelske syndefald. Med denne afgørende vending skulde folkenes forestillingsverdener have skilt sig ud fra hinanden og på den måde være kommet hver for sig til det sprog, der svarede til deres karakteregenskaber. Dette skulde da forholde sig til et »sandt poetisk Sprog « ligesom til et fælles grundsprog, der da blev de forskellige folkesprogs åndelige centrum. Ordet Hjertesprog forklares iøvrigt ved et citat af Europa, Frankrig og Napoleon, hvoraf det ses, at Grundtvig forestillede sig, at Gud med sin »Livsaande « havde indblæst mennesket »Billedet af Guddommens Beskuelse for Verden og Mennesket, samt Evne til med Ord at nævne de Billeder «. Disse billeder var det da menneskets bestemmelse at indprente i sit hjerte, for at mennesket kunde blive »Sandhedens aandelige klare Legeme« - hvilket syndefaldet dog, forklarligt nok, forvirrede.

Repræsentant for et sådant hjertesprog er ifølge Grundtvig Martin Luther, som skal have været fri for det renselses-raseri, der ellers er så betegnende for tyskerne, der end ikke gør holdt over for det rene, for Guds ord, idet de vil »rense Historien og Naturvidenskaben fra alle Spor af Bibelens Herredømme«. De lignede i så henseende perserne, hvilket yderligere skulde forklare visse overensstemmelser mellem det tyske og det persiske sprog. Allerede i denne forbindelse frakender Grundtvig tyskerne en sammenhængende folkelig enhed; deres hjerte skulde ikke have knyttet sig til noget åndeligt, men - sådan må vi tolke hans påstande - i det højeste til noget, der hurtigt viste sig som den blotte funktion af det fælles skriftsprog. Til skriftsproget som ydre kendetegn måtte derfor som indre komponent svare stoltheden. Thi kun heri skulde den tyske »tunges« folk have kunnet bringe det til nogen overensstemmelse, da jo netop stoltheden forhindrede enhver indre enighed.

Da den institution, som et fælles skriftsprog er, har karakteren af en overbygning, er der for Grundtvig en afgørende kløft mellem dette og en ægte sjælelig substans. Også i middelalderen skulde man ifølge Grundtvig kun i saksernes stamme og schwabernes stam- 
me have kunnet iagttage indledningen til en lutringsproces. Derom vidner de kejserhuse, der udgik fra Sachsen og Schwaben. Intet af dem formåede at danne Tysklands hjerte; i dets sted kunde alene sproget træde. Schwaberne i Württemberg var ifølge Grundtvig det eneste folk af tysk »tunge«, der havde taget arven efter Luther op: at danne Tysklands hjerte og tunge. Luthers tysk skulde ligefrem være schwabernes hjertesprog og i grunden kun en videreudvikling af sproget i Nibelungenlied, der ifølge Grundtvig var at opfatte som schwabisk, og i den dermed sammenhørende minnesang. (For schwabernes vedkommende synes Grundtvig her at tænke på det middelhøjtyske litteratursprog, for sachsernes vedkommende på det nyhøjtyske skriftsprog, der bygger på samme grund som Luthers tysk.) Grundtvig lægger i denne forbindelse stor vægt på, at digteren Schiller var württemberger.

Disse betragtninger, der er karakteristiske for en universalhistorisk opfattelse, skelner mellem stammebegrebene Sachsen og Schwaben på den ene side og ægte tysk på den anden, hvilket ved første øjekast synes at stride mod den ovenfor anførte fremstilling. Ved nærmere betragtning viser dette skel sig imidlertid at have ideologikritisk relevans. Betegnelsen Schwaben eller Sachsen lader sig nemlig for Grundtvig bestemme ved et ikke-sprogligt her og nu; det gør begrebet om ægte tysk derimod ikke. Grundtvig anvender nemlig dette udtryk om en abstraktion, og det kan af afhandlingen Europa, Frankrig og Napoleon ikke ses, hvilke bestemte egenskaber der tænkes på. Noget tilsvarende gælder betegnelsen ægte tyske fyrster.

Om Grundtvig ved affattelsen af sin afhandling har set nogen forbindelse med frankernes folkestamme eller ikke, er af mere underordnet betydning. Vil man derimod med udgangspunkt i de nævnte betegnelser drage slutninger om en væsentlig struktur, som forfatterens begrebsdannelse er underkastet, så må det virke påfaldende, at lexemerne agte og tydsk tre gange står ved siden af hinanden, og at denne kollokation stilles i modsætning til de i kontexten positivt markerede stammebetegnelser, der vel at mærke optræder uden modificerende (attributivt) adjektiv. Ved denne lingvistisk bestemte analyse lader det sig på det pragmatiske plan erkende, hvilken brug der i den foreliggende kontext gøres af ordet tydsk i kraft af dets specifikke substitutive affinitet. En udfyldning af tompladser i strukturer af samme type kan ligge bag ved den omstændighed, at Grundtvig i den nævnte afhandling direkte taler om, at Roms ånd 
skulde helliggøres ved at lære tysk, idet dette sprog skulde gælde som grundsproget i det hellige romerske rige.

Endnu tydeligere bliver Grundtvig, når han i det videre forløb af sine betragtninger taler om, at netop hovedmændene for det »idealistiske System « Fichte og Schelling stammer fra henholdsvis Sachsen og Württemberg (Schwaben). (Den sidstnævnte var endda udgået fra en af de reformerede klosterskoler i Württemberg, Grundtvig nævner $\mathrm{i}$ forbindelse med et »Hjertesprog $«$.) Grundtvig finder det $\mathrm{i}$ første omgang ulykkeligt, at disse to mænd så lidet fulgte deres egen natur, idet de så helt og holdent tilegnede sig »Tydskheden《 og »Videnskabeligheden « (der her bliver brugt i nedsættende betydning). Men dernæst beklager han også, at det nævnte idealistiske system, så agte tydsk det end var, dog aldrig kunde komme til at gøre sig gældende i Tyskland, ligesom også kejserkronen aldrig har kunnet blive længe i agte tydske fyrstehuses besiddelse. Thi fornuften kan nu engang ikke indtage hjertets plads, hvorfra al stræben efter at forene og afklare må udgå. Det skulde ikke være lykkedes de to filosoffer at forvandle det tyske sprog til et »Hjertesprog《, fordi idealismens stolte fornuft nu engang ikke besad den dertil nødvendige forenende kraft. (Europa, Frankrig og Napoleon s. I43 og I 84 ).

Kort forud i teksten drager Grundtvig en anskueliggørende sammenligning mellem det Fichteske fornuftsbegreb (han hentyder direkte til Critik aller Offenbarung) og det højtyske skriftsprog, der skulde anse sig for hævet over menigmands Plattydsk. Fornuftbegrebet skulde have samme overbygningsfunktion som det højtyske skriftsprog, nemlig at være en over-regional institution. Endvidere giver Grundtvig os at forstå, at en art selvfølelse er konstituerende for begrebet tysker - en selvfølelse, som har erklæret fornuften for det eneste virkelige og som anser det øvrige for virkning, strålebrydning eller refleks. Dette skulde også hænge sammen med, at tyskerne betragtede sig selv som de eneste sande mennesker. Eftersom de nu ikke var blevet bestyrket af den øvrige verden i deres selvfølelse, skulde de ikke have kendt anden udvej end at betvivle de modsigendes virkelighed, hvilket Fichte i sin Wissenschaftslehre skal have gjort på en så fremragende måde, at tyskerne taler om den som om det stolteste værk under solen.

På tilsvarende måde skulde naturfilosofien, som den forkyndtes af Schelling, aldrig have formået at bringe sine tilhængere ud over 
en vis egocentrisk forholden sig til tingene. Også den skulde altså ikke føre videre, men kun følge et sluttet kredsløb. På tilsvarende måde går bevægelsen $i$ et digt, Grundtvig skrev i anledning af Napoleons udnævnelse til kejser ( 1804 ). At Schellings identitetslære for Grundtvig har en vis lighed med et fænomen som den ynkelige restauration, der er karakteriseret i det nævnte digt, vilde man også kunne slutte af nogle optegnelser af Grundtvig om Schelling (Grundtvigarkivet fasc. 167, Scharling: Grundtvig og Romantiken s. I38). Der er her tale om en udvikling uden for enhver (Guds-)åbenbaring.

Som medium for en guddommelig åbenbaring betragter Grundtvig det, han kalder den sande poesi. Den er for ham det rene lys, der som sådant bryder ind $\mathrm{i}$ vor jordiske verden, ikke farveglansen af den brudte strålevirkning (Europa, Frankrig og Napoleon s. I Io og I42. Jf. også digtet Kiærminde-Bladet. Til Ingemann, I8 I 7.) Som fremtrædende eksempel på denne vurdering af poesien citeres to strofer af tilegnelsesdigtet til Grundtvigs fader i Nytaarsnat i 8ı. Farveglans, kredsbevægelse har ligesom skum på vandet noget at gøre med en såkaldt komisk effekt. Men naturfilosofien og Napoleons tilsynekomst hører dog hos Grundtvig ikke til samme åndshistoriske kategori, omend de to fænomener er at betragte under samme historiske aspekt. Grundtvig gør nemlig en tydelig forskel mellem en sanselig og en åndelig idealisme på den ene side, og en sanselig og en åndelig realisme på den anden side. Sanselig idealisme kan blive til sanselig realisme, hvad der i Grundtvigs begrebsverden kaldes materialisme, mens åndelig idealisme bliver til naturalisme, hvilket for det første forklarer, at der af idealisten Schelling kunde blive en naturfilosof, og for det andet også gør det mere plausibelt, at denne naturfilosofi kunde komme til orde $\mathrm{i}$ et folk, hvis retning syntes at være afgjort idealistisk.

Men da materialismen har svært ved at forliges med den åndelige idealisme, medens naturalismen ligefrem måtte betragtes som en ny fremtrædelsesform for netop den åndelige idealisme - hvorimod materialismen forholder sig til den sanselige idealisme - var der for et fænomen som Napoleon kun den udvej tilbage at blive naturfilosof for at vinde Tysklands »Hjerte« og for at bemægtige sig den idealistiske struktur, gennem hvilken det vilde blive ham muligt materielt at beherske hele verden. 